\title{
URGENSI NILAI-NILAI RELIGIUS DALAM KEHIDUPAN MASYARAKAT HETEROGEN DI INDONESIA
}

\author{
Mardan Umar \\ Dosen Fakultas Ilmu Sosial Universitas Negeri Manado \\ mardanumar@unima.ac.id
}

\begin{abstract}
ABSTRAK
The focus issue in this discussion is how the urgency of fostering religious values in public life heterogeneous in Indonesia and how to provide guidance in religious values in public life heterogeneous in Indonesia?. The purpose of this study was to describe the urgency of fostering religious values in public life heterogeneous in Indonesia and to provide guidance in religious values in the life of a heterogeneous society in Indonesia. The results of this study indicate that the Indonesian people have an emphasis in terms of harmony in the lives of its people. This can be seen in the first principle of Pancasila that Almighty God. Therefore, development of religious values in public life Indonesia is considered very important. Formation of religious values can be reached through religious education to reinforce faith in the truth of religion and its values. In addition, the formation of religious values do habituation through worship that is manifested in the behavior of everyday life. Fostering religious values also need to be supported by the appreciation of the values of religion since from the family, school and community.
\end{abstract}

Keywords: building, value, religious, heterogeneous.

\section{PENDAHULUAN}

Pembinaan nilai-nilai religius sangat penting bagi masyarakat heterogen. Indonesia sebagai negara yang heterogen tentu memiliki landasan filosofis yang kuat tentang kehidupan beragama. Banyak isu yang bermunculan terkait dengan ideologi yang dianut oleh negara ini, mulai dari upaya merusak tatanan kehidupan dengan isu-isu suku, ras dan golongan sampai dengan benturan-benturan golongan agama. Tentu saja hal ini menjadi tantangan tersendiri bagi eksistensi masyarakat Indonesia yang begitu beragam baik dari aspek suku, ras, golongan dan agama. Masyarakat sebagai salah satu tempat implementasi nilainilai kepercayaan kepada Tuhan melalui ibadah ritual keagamaan, masyarakat juga sekaligus sebagai pelestari pesan-pesan ideologis dan kultural untuk dijadikan pedoman bagi warga negara Indonesia dalam berbangsa dan bernegara.

Nilai-nilai religius yang terkandung dalam setiap sikap dan perilaku hidup berbangsa dan bernegara seharusnya menjadi perekat dalam menjalani kehidupan di tengah heterogenitas masyarakat Indonesia yang memang dikenal memiliki keanekaragaman dalam hal suku, agama, ras serta golongan. Keanekaragaman ini patutlah menjadi kekayaan yang memberi warna bagi kehidupan masyarakat dan bukan menjadi sumber perpecahan dan konflik. Indonesia sudah belajar banyak mengenai konflik horizontal dengan berbagai isu yang berkembang, sehingga sudah saatnya untuk merancang suatu strategi dan model kehidupan masyarakat yang tenteram dan nyaman di tengah heterogenitas dan pluralisme bangsa dalam bingkai Negara Kesatuan Republik Indonesia (NKRI) yang berdasarkan Pancasila.

Heterogenitas dan masyarakat multikultur dapat memberi dapak positif dan negatif dalam kehidupan (Supriati dan Umar, 2018:193). Saat ini, Indonesia terus dihantui dengan ancaman perpecahan dengan berbagai macam isu-isu yang melatarbelakanginya. Konflik intern 
maupun antar golongan masyarakat, suku dan etnis tertentu, bahkan konflik intern dan antar umat beragama tidak jarang terjadi pada berbagai lapisan masyarakat Indonesia. Inilah yang perlu untuk diwaspadai dan diantisipasi lebih awal agar masyarakat masih tetap dapat hidup dengan harmonis, nyaman dan tenteram meskipun di tengah perbedaan dan keanekaragaman yang ada di masyarakat. Selanjutnya, Mulyana (2004: 150) mengatakan bahwa pendidikan nilai dihadapkan pada benturan dan pergeseran nilai sebagai akibat dari kemajuan iptek dan perluasan pergaulan manusia. Benturan nilai terjadi pada wilayah nilai secara konseptual, sedangkan pergeseran nilai terjadi pada perilaku kehidupan seharihari.

Oleh karena itu, pembinaan nilai luhur yang terkandung dalam agama perlu dilakukan melalui berbagai upaya, seperti melalui proses pendidikan agama, latihan dan pembiasaan dan peneladanan. Dalam konteks sosio kultural, pendidikan merupakan proses untuk membudayakan nilai-nilai. Sebagaimana pandangan H.M Arifin (2000: 36) yang menyatakan bahwa pendidikan merupakan alat pembudayaan (enkulturasi) umat manusia yang paling diperlukan di antara keperluan hidupnya, meskipun pendidikan pada mulanya berkembang dari sumber kultural umat itu sendiri.

Berdasarkan uraian tersebut, maka perlu untuk mengkaji tentang bagaimana upaya pembinaan nilai-nilai religius dalam kehidupan masyarakat heterogen di Indonesia. Upaya pembinaan tersebut diarahkan pada kehidupan yang harmonis dalam keberagaman (heterogenitas) masyarakat khususnya dalam hal agama.

\section{PEMBAHASAN}

\section{Konsep Nilai}

Secara garis besar, nilai dibagi dalam dua kelompok yaitu nilai nurani (values of being) dan nilai-nilai memberi (values of giving). Nilai-nilai nurani adalah nilai yang ada dalam diri manusia kemudian berkembang menjadi perilaku serta cara kita memperlakukan orang lain. Yang termasuk nilai nurani adalah kejujuran, keberanian, cinta damai, keandalan diri, potensi, disiplin, tahu batas, kemurnian dan kesusilaan. Sedangkan nilai memberi adalah nilai yang dipraktekan atau diberikan kemudian akan diterima sebanyak yang diberikan. Yang termasuk kelompok nilai-nilai memberi adalah setia, dapat dipercaya, hormat, cinta, kasih sayang, peka, tidak egois, baik hati, ramah, adil dan murah hati (Elmubarok, 2008:7).

Frankael (Djahiri, 1958: 20) menyebutkan nilai atau value merupakan ide atau konsep yang bersifat abstrak tentang apa yang dipikirkan seseorang atau dianggap penting oleh seseorang. Nilai biasanya mengacu pada estetika (keindahan), etika (pola laku), logika (benar salah) atau keadilan (justice). Nilai membuat orang untuk berbuat terarah, indah, baik, efisien, dan berharga, serta adil dan benar. Sedangkan Roceach \& Bank (Kartawisastra, 1980:1) mendefinisikan nilai sebagai suatu tipe kepercayaan yang berada dalam ruang lingkup sistem kepercayaan, dimana seseorang harus bertindak atau menghindari suatu tindakan atau mengenai suatu yang pantas atau tidak pantas dikerjakan, dimiliki dan dipercayai.

Selain itu, Kupperman (Mulyana, 2004: 9) mengatakan bahwa nilai adalah patikan normatif yang mempengaruhi manusia dalam menentukan pilihannya diantara cara-cara tindakan alternatif. Pendapat ini memberikan penekanan pada norma sebagai faktor luar yang mempengaruhi perilaku manusia.

Dengan demikian, nilai yang diyakini oleh setiap orang seharusnya menjadi patokan dan standar baginya dalam berperilaku. Pada masyarakat Indonesia yang berlandaskan pada nilai ketuhanan (religius) sudah seharusnya menjadi acuan dalam kehidupan masyarakatnya. Oleh sebab itu, pengembangan nilai religius seseorang perlu diarahkan sejak awal dari anak-anak, remaja dan dewasa. Hal ini sesuai dengan pendapat Moran yang dikutip Soelaeman (Latif, 2009: 75-76) yang mengungkapkan tahapan perkembangan religi mulai anak-anak sebagai tahapan simply 
religious, kemudian memasuki masa remaja dan dewasa.

\section{Nilai Religius}

Religius sebenarnya berasal dari kata religion atau religious yang berarti agama dalam bahasa Inggris. Kata ini awalnya bersumber dari istilah latin religie yaitu re berarti kembali dan ligere artinya terkait atau terikat (Sauri, 2010:115). Menurut Sauri, agama atau religi merupakan suatu sistem ajaran tentang Tuhan, di mana penganutnya melakukan tindakan-tindakan ritual, moral, atau sosial atas dasar aturan-aturanNya. Oleh sebab itu, secara substansial, agama mencakup aspek kredial (doktrin), ritual (cara berhubungan dengan Tuhan), moral (aturan berperilaku) dan sosial (aturan hidup bermasyarakat (Sauri, 2010:120). Dengan demikian, seorang yang beragama harus memiliki nilai-nilai keberagamaan (religiusitas) yang diwujudkan dalam kehidupan sehari-hari.

Fase religius (religious) termasuk dalam fase ketiga (dewasa) dalam kehidupan beragama seseorang, di mana seseorang merealisasikan agama dalam kehidupan atas dasar kerelaan dan secara sungguh-sungguh. Fase ini sudah lebih tinggi dibanding fase pertama simply religious yaitu fase kanakkanak yang beragama secara sederhana, mudah percaya dan bersifat reseptif, sedangkan fase berikutnya adalah fase remaja sebagai acquiring a religion fase di mana seseorang menggali kebenaran agama (Goran dalam Soelaeman, 1988).

Untuk menilai kepemilikan nilai religius dalam diri seseorang tidak bisa hanya dilakukan dengan pertanyaan-pertanyaan menyangkut pengetahuan agama saja melainkan juga dengan sikap dan perilaku yang ditampilkan sebagai perwujudan dari tata nilai dan ajaran yang dianutnya. Perwujudan nilai religius tersebut dapat terlihat melalui ibadah sebagai bentuk ketundukan, ketaatan dan penyerahan diri. Kemudian dalam bentuk sikap dan perbuatan (akhlak) sehari-hari.

Setidaknya ada tiga kriteria religius, yaitu: (1) keterlibatan diri dengan yang Mutlak;
(2) pengaitan perilaku secara sadar dengan sistem nilai yang bersumber dari yang Mutlak; dan (3) memasrahkan diri, hidup, dan matinya kepada yang Mutlak. Pada orang-orang religius, keterkaitan yang kuat pada keimanan cenderung membentuk segala watak dan kehidupannya. Jika dikaitkan dengan agama sebagai sumber nilai, maka religiusitas merupakan keterkaitan pada nilai-nilai agama, baik dalam menentukan sikap hidup ataupun dalam melakukan suatu perbuatan. Hal ini mengindikasikan bahwa religiusitas berarti penyerahan diri secara keseluruhan kepada Yang Maha Mutlak (Tuhan) yang diwujudkan dalam sikap dan perilaku sesuai dengan nilainilai dan ajaran yang diyakininya.

\section{Relevansi Pancasila dan Nilai Religius}

Indonesia sebagai negara yang berlandaskan Pancasila dengan semboyan Bhineka Tunggal Ika, sepantasnya menjadi negara yang menjunjung tinggi nilai-nilai keragaman dan perbedaan. Keanekaragaman masyarakat Indonesia mesti menjadi sumber kekayaan hidup masyarakat untuk membangun tatanan kehidupan yang harmonis dan bersinergi satu sama lain. Termasuk di dalamnya sinergi antara nilai-nilai ideologi yang dianut masyarakat Indonesia dengan nilainilai religiusitas atau nilai agama.

Nilai-nilai dasar yang dikandung Pancasila sebenarnya tidak sedikitpun melanggar nilai-nilai agama. Ketuhanan, kemanusiaan, persatuan, musyawarah dan keadilan sebagai nilai-nilai yang ada dalam Pancasila sama sekali tidak melanggar ajaran agama bahkan merupakan sebagian dari nilainilai religi yang perlu dilestarikan.

Oleh karena itu, penguatan akan nilainilai Pancasila yang relevan dengan nilai-nilai agama perlu dikembangkan dan dimunculkan dalam kehidupan masyarakat Indonesia. Hal ini merupakan upaya untuk menekan munculnya pemahaman yang keliru akan makna berbangsa dan bernegara. Tafsir (2008:156) menjelaskan bahwa inti (core) dari Pancasila ada pada sila pertama: Ketuhanan Yang Maha Esa. Sebenarnya konsep ini merupakan turunan dari 
UUD 1945 dengan petikan teks: "Atas berkat Rahmat Allah ..." yang tertulis dalam Pembukaan UUD 1945, selanjutnya dijabarkan dalam aturan perundang-undangan. Hal ini jelas menunjukkan bahwa Indonesia merupakan negara yang memiliki kecenderungan pada nilai-nilai religius sejak awal berdirinya.

Sebelum mengkaji lebih jauh tentang nilai-nilai Pancasila, cobalah untuk mengingat gambar garuda pancasila yang terpampang di ruang kantor, sekolah atau di baju seragam pemain nasional sepakbola Indonesia. Gambar garuda yang di dadanya terdapat lima simbol dasar negara yaitu bintang yang mewakili sila pertama ketuhanan yang maha esa, kemudian rantai, yang mewakili sila kedua kemanusiaan yang adil dan beradab. Selanjutnya pohon beringin yang mengartikan persatuan Indonesia, sila keempat kerakyatan yang dipimpin oleh hikmat kebijaksanaan dalam permusyawaratan perwakilan ditandai dengan kepala banteng dan sila kelima keadilan sosial bagi seluruh rakyat Indonesia yang ditandai dengan gambar padi dan kapas.

Posisi gambar bintang sebagai simbol sila pertama Ketuhanan Yang Maha Esa, terletak di tengah-tengah semua sila tersebut. Kemungkinan ini memiliki makna bahwa nilai ketuhanan merupakan inti dari semua sila yang ada dalam dasar negara. Selain itu, posisi tersebut sebenarnya menegaskan bahwa nilai ketuhanan menjadi inti dan landasan utama dalam perilaku berbangsa dan bernegara. Tafsir (2008:53) menyebutkan makna dari kelima sila dalam Pancasila. Menurutnya, sila pertama menegaskan bahwa orang Indonesia harus beriman kepada Tuhan YME menurut agamanya masing-masing. Makna penting dalam nilai ini adalah tidak boleh berkembangnya sekularisme dan atheisme. Nilai ini menjiwai empat nilai lainnya. Dengan demikian, nilai kedua kemanusiaan yang adil dan beradab berdasarkan keimanan kepada Tuhan YME, nilai ketiga persatuan Indonesia yang berdasarkan keimanan kepada Tuhan YME, keempat kerakyatan yang dipimpin oleh hikmat kebijaksanaan dalam permusyawaratan perwakilan yang berdasarkan keimanan kepada
Tuhan YME, dan kelima keadilan sosial bagi seluruh rakyat Indonesia yang berdasarkan keimanan kepada Tuhan YME.

Nilai pertama mempunyai fungsi ganda, pertama ia merupakan salah satu dari lima nilai dasar, dan yang kedua, ia menempati inti (core) yang menjiwai empat nilai lainnya. Kelima nilai dalam Pancasila merupakan nilai dasar yang bila dijabarkan akan melahirkan nilai-nilai lain yang dapat dijadikan sumber dalam mengembangkan budaya bangsa. Akan tetapi, perlu kembali ditegaskan bahwa semua nilainilai tersebut harus senantiasa dilandasi, dijiwai, dituntun dan diarahkan oleh keimanan kepada Tuhan YME.

Oleh karena itu, core value (nilai inti) dari Pancasila adalah keimanan dan ketaatan kepada Tuhan YME, yang mewajibkan warga negara beragama dan melandasi setiap perilaku berbangsa dan bernegara dengan ajaran agama. Sehingga dalam kehidupan masyarakat, nilainilai agama harus senantiasa mewarnai setiap penanaman nilai-nilai dasar kehidupan yang ada dalam perilaku dan interaksi sesama anggota masyarakat.

Konsep di atas pula perlu diwujudkan dalam kehidupan masyarakat untuk memperkuat nilainilai ideologi Pancasila yang bersinergi dengan nilai-nilai agama. Disinilah pentingnya sebuah model internalisasi dan implementasi nilai-nilai religi dalam kehidupan masyarakat yang heterogen.

\section{Pembinaan Nilai Religius}

Dalam pandangan Islam, banyak cara yang dapat ditempuh untuk membina nilai agama pada pemeluknya, di antaranya melalui ceramah, pembiasaan/latihan, keteladanan (uswah) serta upaya lainnya yang sesuai dengan prinsip Islam.

Nilai agama tidak hanya dimengerti dan dipahami sebagai pengetahuan semata, namun perlu diimplementasikan dalam kehidupan sehari-hari. Oleh sebab itu, lingkungan sekitar memiliki peran yang cukup penting dalam membentuk pribadi yang religius. Sebanyak apapun pengetahuan tentang agama namun jika tidak diamalkan maka sama halnya dengan 
pohon yang tidak berbuah. Artinya ilmu yang dimiliki tidak memberikan buah amal bagi dirinya.

Peran pendidik, orang tua, pemuka agama, dan semua elemen di masyarakat juga perlu dikedepankan. Teladan yang baik akan membantu pembinaan nilai-nilai religius dalam masyarakat. Menurut Ulwan (1992: 78) mengemukakan bahwa dalam pendidikan keteladanan merupakan salah satu metode yang lebih efektif dalam menanamkan nilai spiritual dan sosial dalam diri seseorang. Hal ini mengindikasikan bahwa teladan sikap yang baik penting untuk membentuk masyarakat dengan nilai-nilai religius.

Keteladanan (uswah) merupakan salah satu metode pendidikan dalam Islam telah ada sejak Rasulullah disebut Allah sebagai figur yang layak diteladani, seperti tercantum dalam Q.S. Al Ahzab (33): 21 yang menyatakan bahwa pada diri Rasulullah terdapat suri teladan yang patut dicontoh. Ayat tersebut menunjukkan bahwa pembinaan akhlak mulia memerlukan contoh perilaku yang tampak dalam proses pendidikan yakni keteladanan. Allah mengutus Nabi dari salah seorang manusia agar manusia lain dapat mengamatinya dengan panca inderanya. Sehingga dengan demikian manusia dapat mengikuti perilaku sesuai dengan kehendak Allah dan berdasarkan fitrah kemanusiaannya.

Dalam Q.S. Fushshilat (41): 6 terdapat seruan untuk manusia dalam meneladani Nabi berkenaan dengan posisinya sebagai manusia dan utusan Allah. Ayat itu setidaknya memberikan dua aspek penting dalam diri Nabi Muhammad Saw. yaitu:

\section{Aspek kemanusiaan}

Aspek kemanusiaan pada umumnya dimiliki oleh manusia sebagai makhluk psiko fisik. Nabi sebagai manusia memiliki sifat kemanusiaan seperti memerlukan makan minum, berkeluarga, lahir, dewasa, tua dan meninggal dunia. Memiliki keinginan dan harapan, senang dan sedih dan sifat lainnya. Namun Nabi mampu menunjukkan sikap dan perilaku yang baik. Inilah yang menjadi bahan pertimbangan agar manusia mencontohi Nabi
Muhammad saw sebagai sosok uswatun hasanah.

2. Aspek Kenabian

Nabi menjadi tokoh teladan karena beliau terpercaya kebenaran perkataan, sikap dan perbuatannya. Seorang yang benar perkataan, sikap dan perbuatan dalam aktifitas sehari-hari dapat juga dijadikan contoh. Dengan demikian, manusia dapat meneladani seseorang ketika dia mempercayainya sebagai orang yang benar dan layak dicontoh. Di zaman Nabi, sahabatsahabatnya mencontohi perilaku Nabi disebabkan karena mereka percaya dan yakin bahwa Nabi akan membawa mereka kepada kehidupan yang baik dan mencapai kebahagiaan di dunia dan di akhirat. Karena itu keteladanan kepada Nabi berangkat dari kepercayaan, keyakinan dan keimanan.

Mustari (2014:3-4) mengemukakan bahwa ada lima unsur yang dapat mengembangkan manusia menjadi religius, yaitu keyakinan agama, ibadah, pengetahuan agama, pengalaman agama, dan konsekuensi dari keempat unsur tersebut.

1. Keyakinan agama adalah kepercayaan atas doktrin ketuhanan seperti percaya terhadap adanya Tuhan, malaikat, akhirat, syurga, neraka, takdir, dan lain-lain. Tanpa keimanan memang tidak akan tampak keberagamaan. Keimanan yang abstrak tersebut perlu didukung oleh perilaku keagamaan yang bersifat praktis yaitu ibadah.

2. Ibadah adalah cara melakukan penyembahan kepada Tuhan dengan segala rangkaiannya. Ibadah itu dapat menjaga keimanan, memberikan garis pemisah antara manusia itu sendiri dengan jiwa yang mengajaknya pada kejahatan. Ibadah itu pula yang menimbulkan rasa cinta pada keluhuran, gemar mengerjakan akhlak yang mulia dan amal perbuatan yang baik dan suci.

3. Pengetahuan agama adalah pengetahuan tentang ajaran agama meliputi berbagai segi dalam suatu agama. Misalnya pengetahuan tentang sembahyang, puasa, zakat dan sebagainya. pengetahuan agama pun berupa pengetahuan tentang sejarah nabi, 
peninggalan, cita-cita yang menjadi panutan dan teladan umat.

4. Pengalaman agama adalah perasaan yang dialami orang beragama, seperti rasa tenang, tenteram, bahagia, syukur, patuh, taat, takut, menyesal, bertobat dan sebagainya. pengalaman keagamaan ini terkadang cukup mendalam dalam pribadi seseorang.

5. Aktualisasi dari doktrin agama yang dihayati seseorang yang berupa sikap, ucapan, dan perilaku atau tindakan. Dengan demikian, hal ini bersifat agregasi (penjumlahan) dari unsur lain. Walaupun demikian, sering kali pengetahuan beragama tidak berkonsekuensi pada perilaku keagamaan.

Sukanto dalam Mustari (2014:4) menyatakan bahwa proses pemanusiaan sesuai dengan agama sebenarnya adalah proses internalisasi iman, nilai-nilai, pengetahuan dan keterampilan dalam konteks mengakui dan mewujudkan nilai-nilai itu ke dalam amal saleh. Proses internalisasi ini baru bisa terjadi, jika ada proses interaksi antara kesadaran manusia dengan kehendak Tuhan yang dibawa kepada komunikasi sosial. Menginternalisasi artinya "membatinkan" atau "merumahkan dalam diri" atau "mengintern-kan" atau "menempatkan dalam pemilikan" atau "menjadikan anggota penuh".

Sebagai orang yang beragama, maka sudah tentu nilai religiusitas harus benar-benar tampak dalam bentuk implementasi sikap, perbuatan, atau perilaku serta ucapan dalam kehidupan sehari-hari. Orang yang beragama, mengaku beriman dan bertaqwa kepada Tuhan seharusnya menunjukkan sikap-sikap yang mencerminkan ketaatan pada aturan dan ajaran Tuhan.

Upaya pendidikan agama hanya merupakan salah satu dari berbagai proses pembinaan nilai-nilai religius sebab pendidikan agama yang diberikan melalui ruang kelas, ceramah di tempat ibadah dan di lingkungan masyarakat tidak otomatis membuat masyarakat itu religius. Oleh sebab itu perlu didukung penghayatan nilai-nilai agama sejak dari lingkungan keluarga dan masyarakat. Lingkungan keluarga diyakini sebagai lingkungan pendidikan pertama dan utama dalam menanamkan nilai-nilai luhur kehidupan sebagai landasan berpikir dan bertindak. Sedangkan pendidikan sekolah sebagai tempat menimba ilmu, bergaul dengan guru dan teman sebaya memberikan dampak dalam pembentukan perilaku anak. Demikian pula dengan lingkungan kehidupan masyarakat, baik organisasi maupun interaksi dalam kegiatan sosial lainnya.

Menurut Majid (2010: 63) dalam kehidupan seseorang, selain karena faktor pribadi yang bersangkutan, maka setidaknya ada enam pihak yang turut memberikan "saham" terhadap perkembangan dan pembentukan karakter, yaitu: (1) orang tua, (2) lingkungan bermain, (3) lingkungan bergaul, (4) lingkungan sekolah, (5) lingkungan bekerja, (6) lingkungan bangsa di mana ia berada. Hal ini sesuai pandangan Lickona (1992: 63) yang menegaskan peran penting lingkungan dalam penanaman nilai moral. Menurutnya lingkungan pendidikan seperti sekolah harus menyiapkan lingkungan yang menekankan pada nilai-nilai kebaikan dan memeliharanya sebagai sebuah kesadaran bersama.

Ada tujuh kualitas yang diperlukan dalam pendidikan karakter, yaitu Seven E's (Empowered, Effective, Extended in to the community, Embedded, Engaged, Epistemological, Evaluative). (Majid dan Andayani, 2010: 36-37)

1. Empowered (pemberdayaan). Pemberdayaan diri untuk memberikan pendidikan karakter dengan dimulai dari diri sendiri.

2. Effective, proses harus dilaksanakan dengan efektif dalam arti berhasil dan bermanfaat sesuai dengan harapan.

3. Extended into the community, komunitas harus membantu dan mendukung dalam menanamkan nilai-nilai.

4. Embedded, mengintegrasikan seluruh nilai ke dalam seluruh rangkaian proses dan aktifitas.

5. Engaged, melibatkan komunitas dan menampilkan topik-topik yang esensial.

6. Epistemological, harus ada koherensi antara cara berpikir makna etik dengan upaya yang 
dilakukan untuk membantu peserta didik menerapkannya secara benar.

7. Evaluative, menilai sikap seseorang dalam aktifitasnya setelah memahami dan menghayati suatu nilai.

Pembiasaan dan peneladanan juga sangat penting untuk membudayakan sikap religius tersebut menjadi bagian dari sikap dan pandangan hidup. Kampanye akan pentingnya bersikap dan bertindak sesuai dengan nilai-nilai agama (religiusitas) harus mampu menyaingi iklan dan kampanye lain sehingga masyarakat akan terus diingatkan tentang pentingnya nilai religius dalam kehidupan.

Dengan demikian, pembinaan nilai religius membutuhkan peran dari semua pihak, kerja sama dari berbagai unsur, mulai dari dukungan pemerintah melalui programprogram yang bernuansa religius, penegakan aturan dan hukum yang tegas agar dapat memelihara suasana hidup yang harmonis, serta pendidikan agama di semua lingkungan baik keluarga, sekolah dan masyarakat.

\section{SIMPULAN}

Berdasarkan pembahasan dalam kajian ini, maka dapat disimpulkan bahwa pembinaan nilai religius pada masyarakat Indonesia sangat penting, mengingat Indonesia memiliki keragaman dalam berbagai aspek seperti suku, agama, ras dan golongan. Hal ini tampak pada sila pertama Pancasila yaitu Ketuhanan Yang Maha Esa. Pembinaan nilai religius dalam kehidupan masyarakat Indonesia yang sangat beragam tersebut dapat ditempuh melalui pendidikan agama untuk meneguhkan keyakinan akan kebenaran agama dan nilainilainya. Selain itu, pembinaan nilai religius dapat dilakukan pembiasaan melalui ibadah yang diwujudnyatakan dalam perilaku kehidupan sehari-hari. Pembinaan nilai religius juga perlu didukung dengan penghayatan nilainilai agama sejak dari lingkungan keluarga, sekolah dan masyarakat.

Untuk mencapai tujuan kehidupan yang harmonis dalam kehidupan masyarakat heterogen di Indonesia, maka perlu adanya pembinaan nilai religius. Upaya tersebut harus menjadi gerakan bersama yang terprogram dengan baik oleh pemerintah dan diimplementasikan secara bersama-sama oleh semua elemen masyarakat, mulai dari lingkup keluarga, sekolah dan masyarakat menuju kehidupan bangsa dan negara yang harmonis.

\section{DAFTAR PUSTAKA}

Arifin, H.M. (2000). Filsafat Pendidikan Islam, Bandung: Remaja Rosdakarya.

Djahiri, A.K. (1996). Menelusuri Dunia Afektif. Bandung: Lab. Pengajaran PMP IKIP Bandung. Elmubarok, Z. (2008). Membumikan Pendidikan Nilai. Bandung: Alfabeta.

Majid, A. (2010). "Peranan Pendidik dalam Upaya Membentuk Karakter Peserta Didik". Jurnal Pendidikan Karakter. 2, (2), 58-77.

Majid, A. dan Andayani, D. (2010). Pendidikan Karakter dalam Perspektif Islam. Bandung: Insan Cita Utama.

Mulyana, R. (2004). Mengartikulasikan Pendidikan Nilai. Bandung: Alfabeta.

Mustari, M. (2014), Nilai Karakter,Refleksi Untuk Pendidikan, Jakarta: PT. RajaGrafindo Persada.

Sauri, S. (2010). "Membangun Karakter Melalui Pembinaan Profesionalisme Guru Berbasis Pendidikan Nilai". Jurnal Pendidikan Karakter. 2, (2), 1-15.

Supriati, A. \& M. Umar, (2018), Optimization of the Civic Education as the effort to Strengthen National Character in Multicultural Community. Advances in Social Science, Education andHumanities Research, Vol. 251. p. 193-196.

Tafsir, A. (2008). Filsafat Pendidikan Islami. Bandung: Remaja Rosdakarya.

Ulwan, N.A (1992). Mengembangkan Kepribadian Anak. Bandung: Rosdakarya. 